\title{
Introduction: Friends \& Enemies of the Word
}

Osip Mandelstam was born in I89I of middle-class Jewish parents, grew up in St. Petersburg, and received his formal education in part there, in part in France and Germany. He studied philology, and, though he never took an academic degree or acquired much erudition, his word-love was deep and very sure of itself and became in his imagination a kind of substitute for the warm and secure domesticity he was not otherwise to know. His first poems, published in 1909-1910, whatever traces they might show of his apprenticeship to Symbolism, were of a marked originality, and the sense of a stillness in them, the sense of a motion arrested and about to resume, the sense of transition now strike the attentive reader as the distinctive features of his early work. Crowded between two worlds, the nineteenth century dying, the twentieth in ominous labor, it is small wonder that Mandelstam's talent, like that of so many of his contemporaries, lent itself to apocalyptic expectationsto a vision of the end of the world that at the same time saw a terrible beauty stirring to be born out of that death-grass growing in the streets of St. Petersburg, paradoxically making of it "the most advanced city in the world." 1

No doubt these apocalyptic expectations had been nourished by the mystical Marxism of his early years as well as by his later Christianity. Writing from Paris in 1908 to his former teacher, V. V. Gippius, Mandelstam affirmed: "My first religious experiences date from the period of my childish infatuation with Marxist dogma and can't be separated from that infatuation." 2 He saw a culture marked for death, and a new barbarism, terrifying yet perhaps potentially creative, waiting at the gates. Looking back on his youth through the acquired irony of maturity, Mandelstam wrote: "I perceived the entire world as an economy, a human economy - and .... I heard ... the burgeoning and increase, not of the barley in its

Note: A previous version of this introductory essay appeared in Texas Studies in Language and Literature $17: 357-373$ and was reprinted, with a few changes, in Arion 2, no. 4 (1976). 
ear ... but of the world, the capitalist world, that was ripening in order to fall!"3

Mandelstam was early associated with the journal Apollon and with Acmeism, a literary movement that had strong Classicist, NeoParnassian overtones. Its leader was Nikolai Gumilev, whose stance, given the Russian context, had strong analogies with that of the early Ezra Pound.

The Acmeists were at least as opposed as the Symbolists to the powerful Russian-intelligentsia tradition of a socially useful and uplifting art. Like the Symbolists, they believed in the sacred nature of the word and the autonomy and integrity of the work of artbut not, like the Symbolists, in the priesthood of poets. And they rebelled against a certain excess, the decadence of Symbolism-its obscurity, its glorification of self-indulgent and self-pitying attitudes, its love of oblivion and the abyss, its compulsive obsession with "other worlds." The Acmeists tried to emphasize clarity, lucidity, forthrightness, and, above all, this-worldliness, a sense of being of the earth, earthy. At the same time they attempted to restore a traditional, rational formality, and Gumilev, though certainly not Mandelstam, indulged a certain heroic, Hemingway-like, aristocratic athleticism, meant among other things to distinguish him from the mob. I think it fair to sum up the major thrust of the Acmeist revolt against Symbolism not in its aristocraticism but, on the contrary, in its emphasis on the poet as a man among men, its this-worldliness, its attempt to return to earth. Mandelstam's association with Acmeism was an important chapter in his life; yet, although his essay "About the Nature of the Word" was the most complete and the most eloquent expression of Acmeism and its relation to Symbolism, he was never a "leader" or even much of a "member" of that or any other group. He did, however, participate in that will toward a new taste-formation in which he himself saw the historical significance of Acmeism. ${ }^{4}$

Like other poets of his generation, Mandelstam reacted to the Bolshevik Revolution at first in terms of his apocalyptic expectations, welcoming it with some hope, not unmixed with dread and apprehension. From the I920's on, he saw that apprehension more and more insistently confirmed. It became increasingly clear that the revolution he had thought might produce a new universalizing human domesticity, the new "Social Gothic" he had hoped for, was not taking place. The barbarism at the gates was a repressive, not 
a creative barbarism. He found it increasingly difficult to survive in the Soviet context, though his spirit remained in general cheerful and indomitable. In 1934, the Soviet press ceased to publish his work; he was exiled, under very harsh circumstances, to the provincial town of Voronezh. In I937, he was arrested and sent to the Far East, where, in a transit camp in Vladivostok, in the winter of 1938 , he died. For almost two decades, his name disappeared from print in the USSR.

In 1973, a slender volume of Mandelstam's poems appeared in the Biblioteka poeta series, in a limited edition, more than half of which was exported abroad, and then by curious circumnavigations much of it reimported! From the introduction to this volume by the Socialist Realist critic Alexander Dymshits, in his own way trying, I suppose, to bring Mandelstam back, one might gather that Mandelstam "cut himself off" from literature in 1934 as an act of eccentric self-isolation and that he died in 1938 of some unnamed but probably self-inflicted and equally eccentric illness $!^{5}$ Nevertheless, thanks very largely to the efforts of his widow and a number of devoted scholars and admirers both in the Soviet Union and abroad, Mandelstam is now commonly, even if still too often in the USSR only tacitly, acknowledged as one of the great Russian poets of the twentieth century.

Mandelstam's criticism has to this day been seriously underestimated. He does not provide us with a new methodology and in general tends to take a deflating view of the importance of methodologies. Nor is he quick to put on the judge's robes and consign his fellow poets to this or that circle of critical hell. There are poets he speaks of frowningly and with displeasure in one context who of ten appear with vibrantly positive force elsewhere in his work. In his essays, there is some sarcasm directed at poets like Akhmatova and Tsvetaeva, whom he was elsewhere to cherish. Andrei Biely appears as a kind of villain, yet became the inspiration later for a whole cycle of poems; and it is Biely who must be thought of as a kind of interlocutor for the essay on Dante. A number of figures who appear in these essays are particularly close to Mandelstam in an almost intimate, personal sense-Villon, Chaadaev, the historian Kliuchevsky - without his necessarily making universal claims for them. A number of poets whom he treats rather harshly-Mayakovsky, Kruchenykh, Balmont-at the same time clearly command his respect. He offers us neither the luxury of an imitable method nor 
that of an authoritative juridical decision, and so interest in him as critic in our age of luxurious criticism has been limited to the illumination his criticism provides his poetry.

This is of course no mean interest. He was a poet first, and no doubt his criticism must be approached from the perspective of his poetry and in relation to his poetic practice. At the same time, it becomes immediately apparent that the quality and gift of his criticism partake of the quality and gift of his poetry while remaining, properly, prose.

Just as T. S. Eliot's interest in Dante and the English metaphysical poets, Pound's in the troubadors and Confucius, Wallace Stevens' Symbolist essays in esthetics cannot be seen apart from their own poetry, so Mandelstam's "Conversation about Dante" has to be read, I think, as an incipient project for a new Divine Comedy, or at the very least as the ringing affirmation of a sense of poetic identity so closely and passionately held as to make mere mistakes of historical detail or social interpretation seem relatively insignificant. ${ }^{6}$

It is interesting to compare it with Eliot's essays on Dante. The poets attempt to rescue Dante from the Dante scholars. Each, while respectful of the need for knowledge about Dante's time and its cultural assumptions so very different from our own, makes a powerful effort to remain true to his own "amateur" reading of the poem. Each rejects the "antiquarian" Dante and seeks in his work what is potentially alive as poetry.

Yet Eliot's Dante is more like that of the scholars-a formidable and remote figure. Eliot's immediate involvement is with the visual, not far away from the conceptual. "Dante's," he writes, "is a visual imagination," adding that "it is visual in the sense that he lived in an age in which men still saw visions." "There follows a typically Eliotic distinction between "then" and "now." "Then," having been a religious age, turns out to have been better. Its visions were superior to the mere dreaming of "now." For vision, he writes, "was once a more significant, interesting and disciplined kind of dreaming." It might even be presumed to come from above, whereas we "take it for granted that our dreams spring from below." The essays on Dante by Eliot are permeated by a nostalgia for a remote, more integral, more spiritually grounded age.

Mandelstam's involvement is immediate and personal. For him, the essential question is "How many sandals did Alighieri wear out in the course of his poetic work, wandering about on the goatpaths of Italy?" For him, poetry is movement, the embodying, the incar- 
nation, of movement. Elsewhere, Mandelstam repeatedly refers to Verlaine's "Art poétique," and often he substitutes the word mouvement for Verlaine's musique. ${ }^{8}$ His own synonym for poetry was "moving lips," and composition was inseparable from physical movement, from pacing and gesturing. Mandelstam wrote his poems-that is, "fixed" them on paper; abstracted them-only after they had already been composed. ${ }^{9}$ The composition of a poem was a physical process and "another poet" a physical presence.

Mandelstam tries to erase the impression left by Dante's face in the well-known portraits; the aquiline profile, the haughty and superior gaze. Dante, he says, was an exile and a raznochinets (like Mandelstam!), a man of uncertain social background, nervous about his deportment in the presence of the mighty, all too capable of swinging to extremes of self-abasement and self-assertion. It is clear that Mandelstam knew little of the social history of Florence. Dante's pride of lineage is not quite so easily dismissed. Nevertheless, Mandelstam finds his grounding in the text: Dante needed his guide, to make his way properly among the mighty shades!

The visual is by no means absent from the "Conversation about Dante," and even the musical "instruments" with which the essay begins soon turn out to be "images." It is not the visual stasis of a tableau. One senses the physical: incipient movement. In his obsession with architecture, Mandelstam sees the Goethean erstarrte Musik, "frozen music"; and, in weaving, the flow of rivers. Music is motion; words are motion. When he writes about Italian vowels, he talks of their place in the mouth, the mode of their issuance, the movement of the muscles. In his discussion of the "mineralogical" nature of Dante's work - an image of stone borrowed from Novalis -he sees the most solid thing in the world, a rock, as a product of the motion of time and the weather.

It is not that Mandelstam has less than Eliot the sense of a "different" age. What he has is a physical confidence in the rightness of his own presence there, and it is a confidence that survives anachronism and incongruity. To catch the motion-there he concentrated. Mandelstam was obsessed with birds and bird flight to the degree that many of his contemporaries referred to him as "birdlike," though he was in fact a tall, rather well-built and solid man. He is not slow to pick up the images of flight in Dante. This gift of physical sympathy, of susceptibility to motion, is apparent also in his almost physical sense for the presence and movement of cultural epochs. Where does it come from? Where does it go? These are 
questions he is always asking. For Mandelstam, an epoch is also a presence in motion. And he has the sense that Dante's epoch, like his own, is transitional.

He does not in any case attempt to use his acquaintance with Dante as an occasion for feeling superior to his own time. He was of the earth, earthy; and, rightly or wrongly, Mandelstam believed that Dante was a raznocbinets like himself. If the great French critic Gaston Bachelard is right, and a poet's work tends to be dominated metaphorically by one of the four medieval archetypal elements, Mandelstam's "dominant" was earth. ${ }^{10}$ In his reading of Dante, he scarcely notices the fire; and, although air (ascent; flight) and water (rivers; the ocean) recur in powerful images, there is no doubt that the basic element for Mandelstam is earth. Other images acquire their significance fundamentally in their relation to the earth. There is no Nietzschean climbing into the stratosphere, no Zarathustran ascent, the aim of which is to leave earth behind, so that even the return to earth has as its purpose the telling of what is above the earth, what belongs to the heights. For Mandelstam, space is empty and takes on significance only insofar as it can be populated"colonized," he wrote-with earthy images by the human imagination. Of the two aspects of earth, building and burial, Mandelstam emphasized the earth as material crying out to be built: stone as potential sculpture.

If earth and the materials of earth are his "ground bass," the poetic process of building out of the materials of earth is inextricably connected with the Christian music of redemption. Mandelstam's Christianity was by no means a decorative, that is to say, a purely esthetic phenomenon. Nor was it merely the form taken by his deep resistance to barbaric Stalinism. It was more fundamental and more complex.

"Christian art," he wrote, "is always an action based on the great idea of redemption." This is from the fragments of the unpublished essay "Pushkin and Scriabin." It was written, or at least begun, as early as I91 5, on the occasion of Scriabin's death. The passage on Christian art seems to me central and deserves quotation at length:

It [Christian art] is an "imitation of Christ" infinitely various in its manifestations, an eternal return to the single creative act that began our historical era. Christian art is free. It is, in the full meaning of the phrase, "Art for art's sake." No necessity of any kind, even the highest, clouds its bright inner freedom, 
for its prototype, that which it imitates, is the very redemption of the world by Christ. And so, not sacrifice, not redemption in art, but the free and joyful imitation of Christ-that is the keystone of Christian esthetics. ${ }^{11}$

It is a strange kind of estheticism-the imitation of Christ! Like Jesus, the artist redeems the world - but in his art. We are close here to Jakob Böhme, to the old mystic himself, without the intermediacy of Schelling and the German Romantics:

Art cannot be a sacrifice, for a sacrifice has already been made; cannot be redemption, for the world along with the artist has already been redeemed. What then is left? A joyful commerce with the divine, like a game played by the Father with his children, a hide-and-seek of the spirit! The divine illusion of redemption, which is Christian art, is explained precisely by this game Divinity plays with us, permitting us to stray along the byways of mystery so that we would as it were of ourselves come upon salvation, having experienced catharsis, redemption in art. Christian artists are as it were the freedmen of the idea of redemption, rather than slaves; and they are not preachers. ${ }^{12}$

What an extraordinary explication of "art for art's sake" and its consequent "freedom of the artist"! As a kind of Christianity, it places its emphasis not on the crucifixion, not on Golgotha, but on resurrection and transfiguration. It conceives of art as play-the play of a game in which the artist imitates Christ by redeeming the world.

The poet and the architect imitate Christ by endowing the world with meaning, by giving it a form and pattern in their works that is analogous to the form and pattern God made out of the world. The poet is a colonizer, a settler, a kind of Saint George, like the intrepid Russian monks of the period of the Mongol Yoke that Kliuchevsky wrote about; like Chaadaev with his need for form, his vision of unity, his "West." Anticipating Heidegger, Mandelstam wrote: "To build means to fight against emptiness, to hypnotize space. The fine arrow of the Gothic belltower is angry, because the whole idea of it is to stab the sky, to reproach it for being empty." 13 Poets were the shepherds of being.

This freedom of the artist and the builder is therefore not the empty liberty of the unimportant. His mission is to hypnotize space 
and, like Joshua in the Old Testament or the priest in performance of the Eucharist, to make time stand still.

Behold the chalice like a golden sun

Suspended in the air-a splendid moment;

Here must only Greek resound:

To take the whole world in its hands, like a simple apple.

Festive height of the service,

Light in a rounded structure under the dome in July,

That, beyond time, we might, full-chested, sigh

For that meadow where time does not run.

And like eternal noon the Eucharist endures-

All take part, all play and sing,

And in the sight of all, the holy vessel

Flows with unending joy.*14

The poet may redeem the most recalcitrant materials: "There is nothing hungrier than the contemporary state, and a hungry state is more terrible than a hungry man. To show compassion for the state which denies the word is the contemporary poet's civic 'way,' the heroic feat that awaits him." 15 That is a long way from the mere "defense" of poetry, or from the notion, wearily conceded by Eliot, that poetry is probably little more than a superior form of amusement. For Mandelstam, too, it is a game-but a game to be played as seriously as children play games, that is, as a sacred and heroic calling.

For all his juxtaposing of Chinese junks and racers at Verona, Jesus and Joshua, Beethoven and Dante, Verlaine and Villon, incarnation and Ovidian metamorphosis, Mandelstam knows very well what time it is. He never asks, as does the lyrical voice in a Pasternak poem, "What millennium is it out there?" ${ }^{16}$ His feeling for "the age" is one of the qualities of his gift. Not clock time (he disliked clocks and would never have one in his flat), time spatially conceived, but rather Bergsonian time, time as durée, a system of intuited inner connections. Like the lover in his essay, he "gets tangled up in tender names and suddenly remembers that all this

\footnotetext{
* Reprinted, with slight modifications, from Complete Poetry of Osip Emilevich Mandelstam, translated by Burton Raffel and Alla Burago, by permission of the State University of New York Press. Copyright @ 1973 State University of New York.
} 
has happened before." ${ }_{17}$ Shaping form out of matter, life creates pattern; and pattern is repetition.

It is dangerous, the time he lives in. He feels the ominous shift of direction. The nineteenth century, weighed down by "the enormous wings" of its cognitive powers, cannot lift itself from the exhausted shore. ${ }^{18}$ One feels the shadow of an oncoming night. Those essays of the Civil War period, "The Word and Culture" and "Humanism and Modern Life," still vibrate with a certain optimism, still hold the early conjunction of his religious sensibility and his unorthodox interpretation of Marxism. He bopes for a new "Social Gothic," that universalized domesticity, an all-human family. But he sees the other alternative: a new Assyrian age in which "captives swarm like chickens under the feet of the immense king." 19

It is a time of crisis and there is magic in it; the tree is about to become a girl again. It is a time when

Social distinctions and class antagonisms pale before the division of people into friends and enemies of the word. Literally, sheep and goats. I sense, almost physically, the unclean goat smell issuing from the enemies of the word. ${ }^{20}$

Who are these goat-smelling enemies of the word?

Those for whom the word had merely a denotative, a utilitarian meaning. Those for whom its living nature is a secondary or subordinate quality. Propagandists of political parties, philosophers, anthroposophists like Andrei Biely, who, in Mandelstam's view, yoked his great poetic gift to a "Buddhist" worldview. ${ }^{21}$ Those who used the word as slave labor to support some other external structure-a church, a state, a party, a program.

"Friends" were those who believed in the sacred and redemptive power and the psychic nature of the word.

Luther was a poor word-lover; he departed from verbal argument to fling his inkpot at the devil. The literary critics whose response to the anniversary of the death of the great poet Blok was mere lyrical effusion served the word badly, for a critic's minimal task is to establish where the poet's words came from-that is, his poetic genealogy - where he stood in relation to the larger pattern-forming, historical energies of the word. The Moscow "poetesses" pay only half-tribute to the word, for, of the constituent elements of poetry, remembrance and invention, they honor remembrance alone; they are all genealogy, mere traditionalists; while the Futurists blaringly honor invention alone. ${ }^{22}$ 
"Culture has become a church," Mandelstam wrote in I92I, and he hailed the separation of this "church" from the state. It is in this time of transformation and transfiguration that culture assumes a sacred quality, a sacred mission. Within the state, those are friends of the word who acknowledge the statutory independence of culture, who "consult" it, as the princes of old Moscow used to consult the monasteries. But within these monasteries, there were monks and laymen; and Mandelstam identified himself as a layman. Monkish structure-whether Byzantine, or whether the new monasticism of the secularized Russian intelligentsia - was hostile to the word.

Even Literature, with a capital $L$, was hostile. Mandelstam was an Acmeist, but he did not like schools. Still less did he like the way these schools were organizing themselves in the 1920's-preparation for their own slaughter, in which the Stalinist organization of Socialist Realism would later use the rivalries and the acrimonies as well as the phrases and slogans of contending schools in order definitively to decimate them all. As the I920's came to an end and Literature tightened the clamp on Mandelstam, invoking even antisemitism against him, Mandelstam increased the angle of the defiant tilt to his head. More and more he came to distinguish "poetry" from "Literature." Reading his poems at occasional "evenings," he intoned them, I suspect, rather in the manner we have heard from Joseph Brodsky, liturgically. One memoirist writes: "He sang them like a shaman." 23

For friends of the word there was the blessing of the Russian language itself; its Hellenic nature. By "Hellenic," Mandelstam explains, he does not mean that Russian derives etymologically from the Greek. Still less does he refer to the Byzantine cultural heritage-which, in a certain slant of light, he tends to see as "monkish" and dead and hostile or confining to the word. He calls it "the gift of free imagination," or "free embodiment." Just as Aristophanes in The Birds creates a structure out of the rootword eros, the manifold play and stresses of the meaning of "desire" and "desiring," so Mandelstam sees the genius of the Russian language in the great depth and multiple branchings of its root meanings. ${ }^{24}$ So, too, he sees the writer Rozanov looking for "church walls" and finding only Russian words; for Russia had produced no Acropolis, no lasting legal or political structure, and the Russian language was Russian history. ${ }^{25}$ For that reason among others, history is a subject close to Mandelstam. When he listens, he hears it breathe.

A Hellenic language is one in which the word-psyche finds rich 
opportunity for embodiment, without the hindrance of authoritative utilitarian standards.

Mandelstam's Hellenism should not be confused with that program of classical studies that for so long dominated the higher education of Europe and Great Britain. It is not that aristocratic/ priestly key to possession of a mystery that wielded power in a secularizing world still stunned by the sacred. For Mandelstam, "Hellenic" means "human." Perhaps it would be better to call it a kind of creative, procreative projection of the human onto the emptiness of the world. Crucial here is the conception of the utvar', which one may translate as "utensil," except that it has at its root a sense that is not that of "use" but is rather closer to the notions of "creation" and "creature," something "creaturized." It is, he tells us, the insistence on a relatedness between the warmth in the stove and the warmth in the human body. "Christianity," in Mandelstam's definition, is "the Hellenization of death."

Both Victor Terras and Clarence Brown have written eloquently of Mandelstam's "Classicism." 27 It should not be confused with a preference for "high style." There is, as Brown points out, a strong Flemish element, a transformation of the lowliest details of the everyday. Like Villon, Mandelstam has a keen sense of "roast duck," and the vow of which he speaks in his poetry "to the fourth estate," to his fellow raznochintsy, he took as a binding oath.

Yet his interest in Ovid is surely more than identification with a fellow exile, as Brown implies. He cares as much for the poet of the Metamorphoses and the Amores as for the exile of Tristia and Ex Ponte. One is reminded of Ovid's absorption into medieval Christian cosmology as "Saint Ovid the Martyr." It is possible that Mandelstam saw in metamorphosis a kind of resurrection: the creative process itself as death and rebirth, an arresting of the flow of time, "and then, after dwelling in the protracted moment wrested from it," a return, changed by contact with the external, to life. ${ }^{28}$

Nor is "the Classical" simply a matter of Greeks and Romans. "Classical poetry," Mandelstam tells us, "is the poetry of revolution." ${ }^{29} \mathrm{He}$ is not referring to David's historical tableaux or to eighteenth-century pseudo-Classical "tragedy." The Classical is that which is remembered when the mere piety of remembrance fails. It is remembrance energized by a powerful sense of the new, by a sense of what the new requires from the past. The trouble arises, Mandelstam writes, "when, instead of the real past with its deep roots, we get 'former times.' " This is a poetry that has not 
had to wrestle with its conventions: "easily assimilated poetry, a henhouse with a fence around it, a cosy little corner where the domestic fowl cluck and scratch about. This is not work done upon the word but rather a rest from the word." ${ }^{30}$ The Classical is what is required to complete a mode of experience: its necessity. In that sense, Mandelstam refers to the "genuinely Classic" style of Racine and the Classical furies of André Chénier.

$\mathrm{He}$ does not see the Classical as mere translation. In spite of his real devotion to the craft of translating - though his efforts are uneven, they contain some examples of the highest skill-he tended to speak of translation in the pejorative, implying use of the readymade phrase, the formula, the pat device, something mechanical and ready to hand. He did not see the task of the "Classicist" as releasing from the resources of the Russian language those qualities which might make it phonetically or syntactically resemble Latin or Greek, but rather as building out of Russian phonetic materials and the history of the Russian language (Hellenic only in its latent powers of incarnation) its own equivalents of Catullus, Ovid, Racine. It is not Latin or Greek that slumbers in Russian, Mandelstam insists, but the power of Russian itself. "Latin Russian" is therefore a pejorative, and even the commentary on Balmont, that he is the brilliant translator of a nonexistent original, is not praise.

Nor does he care much for Balmont's assumption of superiority to his audience, the fashionably lofty hauteur toward the reader. If the poet has a special relationship to the word-psyche, it is not one that gives him a place on any elevation above the rest of mankind. On the contrary, what distinguishes him from a "literary man" is that he speaks to other men on their own level. The professor, the critic, the litterateur require their elevation; the poet is the same as any other man, if perhaps "not so well made as most." ${ }^{31}$ He has no need to be morally superior. Villon, for instance, was a criminal, a murderer, possibly morally inferior to even the average man of his time, and yet a great poet.

A man speaking to men, with no need to be morally or intellectually superior: yet the poet speaks, and that means he speaks to someone, an addressee, an interlocutor. With its quiet humor and exceptional charm, the essay called "About an Interlocutor" articulates the poet's reaching out past his beleaguered feeling of impending doom, to a very personal reader of some other time, a time beyond that "wing of oncoming night" he felt already encroaching upon him. The essay conveys, among other things, a remarkable 
understanding of those commonly not too well understood poems of Pushkin's about the poet, his publisher, his audience, the powersthat-be. The poet's interlocutor must be someone not too close, not too immediate. He must elicit surprises and carry about him and also invite a certain mystery. But above all he must be someone. He must have particularity. And that particularity must be respected.

The Classic has nothing to do with lofty attitudinizing, but rather with the idea of a human potential fulfilled. In this sense Mandelstam speaks in his poems of the Classic lands of the Mediterranean, of Italy and Greece, "those all-human hills" near Florence, and in the same sense, of the lands of the Caucasus and the Crimea which he associates with the Mediterranean, which for him are part of that "all-human" Mediterranean world. ${ }^{32}$

In a recent impassioned essay, the novelist Arthur A. Cohen has written well of Mandelstam. Like Nadezhda Iakovlevna, who has insisted on it, he has been able to see how the poems of Mandelstam's last years, the "phases" and "cycles," gain from being published complete, all their variants included. He has grasped the mutual implicativeness that joins poem to poem and makes each repetition of a word, a phrase, an image, or an association an addition to the meaning of the cycle. He has gone beyond this to suggest that the poems form a kind of eschatological epic, or that something like an eschatological epic is struggling to be born in them. ${ }^{33}$ I think one finds implications of this in the last great essays as well: in "Fourth Prose," "Conversation about Dante," and Journey to Armenia. Mandelstam's obsessive themes draw together in them. They capture his sense of a civilization coming to an end, and, in the shipwreck of that civilization, they constitute his letter-in-thebottle thrown overboard to find a distant interlocutor in future time.

While the Russian countryside was still being devastated by collectivization and the five-year plans for the forced, rapid industrialization of the Soviet Union were being launched, Mandelstam, who dearly loved travel, went off on what was to be his last extended voluntary journey. He had suffered a writing block for almost five years. The organization and regimentation of the country that preceded and accompanied collectivization and industrialization, including the ever-increasing pressure on writers, editors, and publishers, oppressed his sensibility. Rescuing him from on high at this crucial time, his "protector," Nikolai Bukharin, arranged for him and his wife to go to Armenia. Whether in the long run his association with Bukharin may have precipitated his last arrest and his 
death is a moot point, but, just then, it saved his creative life as a poet. The journey itself, his meeting with Andrei Biely, the therapeutic outburst of "Fourth Prose" set the juices flowing again and the lips moving. The essays are certainly overshadowed by the poems, but they partake of the same qualities and, indeed, the same themes as the poems.

If there is anything that Journey to Armenia is not about, it is not about either the joys of collectivization or the successes of industrialization in Armenia. Whatever expectations may have been aroused by the title-it was a time when writers were going on all kinds of trips and turning them into euphoric odes to the new order - Mandelstam clearly does not aim the essay for entry into the fat privileges of the new writers' elite. Collectivization and industrialization come up briefly in passing, and an occasional journalistic cliché is inserted for the irony with which it flavors the context. One has the impression that Armenia would probably survive the mechanical regulation imposed by the five-year plans.

He does not write only about Armenia, but about everything he carries with him to Armenia as well: his memories of Russia, his interest in Impressionist painting (now revived and revised), his obsession with biological theory, especially that of Lamarck, threaded through long dialogues with the chess-playing biologist, his friend, B. S. Kuzin; and, above all, his passion for language, his philology. As elsewhere, he tells his story by means of significant association rather than linear narrative. A chapter on the island of Sevan and its architectural "digs" is followed by a chapter on Zamoskvorech'e, the old merchants' section of Moscow, setting for so many of the plays of Ostrovsky, dramas of personal and cultural tyranny, and for the poems and essays of Apollon Grigoriev with their exaltation of the "seven-stringed guitar" and the home-soil aspects of Russian nationalism. The fullness of Armenia is contrasted in restrospect with the "watermelon-emptiness of Russia," with Zamoskvorech'e, where Mandelstam himself had lived, and its "cheery little houses" and "nasty little souls and timidly oriented windows." Armenia might survive the five-year plans with their hypostasization of nineteenth-century scientific rationalist "Buddhism"-but Zamoskvorech'e?

In connection with thoughts on evolutionary theory, Mandelstam uses the word "development" (razvitie), which, of course, also has many associations with the five-year plan. It is a word he dislikes: "A plant is a sound evoked by the wand of a termenvox, 
pulsating in a sphere oversaturated with wave processes. It is the envoy of a living storm that rages permanently in the universeakin in equal measure to stone and lightning! A plant in the worldthat is an event, a happening, an arrow; and not boring, bearded 'development'!" ${ }^{44}$ The passage recalls Mandelstam's poem, no. 254, on Lamarck, and carries as well the implicit comparison of "a plant" with "a poem," an ineluctable resemblance to Mandelstam's theory of composition as expressed in "Conversation about Dante" and elsewhere. Even the adjective "bearded" as applied to "development" recalls the Italian idiom Che barba! and the expressive gesture that normally accompanies it. Mandelstam's biological is really poetic theory:

All of us, without suspecting it, are the carriers of an immense embryological experiment: for even the process of remembering, crowned with the victory of memory's effort, is amazingly like the phenomenon of growth. In one as well as the other, there is a sprout, an embryo, the rudiment of a face, half a character, half a sound, the ending of a name, something labial or palatal, a sweet legume on the tongue, that doesn't develop out of itself but only responds to an invitation, only stretches out toward, justifying one's expectation. ${ }^{35}$

That a Jew should identify closely with Armenia and Armenians is of course not at all unusual or surprising, but an instance of the natural kinship of gifted diasporic peoples, often persecuted, often mistaken one for the other by "the heathen." What country, as Nadezhda Mandelstam asked, could be more worthy of being called "the younger sister of Judea"? ${ }^{36}$ Since the mood is eschatological, there is Mount Ararat, where the ark came to rest; and there are the Gog and Magog of the long dark night of imperial oriental siege and conquest. But Armenia resembles Greece and Italy as much as Judea: it is a wine-growing region, with the culture habits that accompany the grape, and there are even traces of an ancient goat cult in the mountains. Above all, Mandelstam is fascinated by the jangling of the philological keys, with his discovery that the Japhetic verbs "to see," "to hear," and "to understand" once coalesced into a single semantic bundle. ${ }^{37}$

Armenia is the first Christian kingdom and the longest Christian survivor as a cultural entity. It is the homeland of Christian architecture-both the Romanesque and the Gothic. Mandelstam sees it as a place of renewal, whose language will be studied when the 
phonetic ores of Europe and America are all used up, a place lifted outside of time like the Eucharist. Armenians were a people

whom you respect, with whom you sympathize, of whom you are, though a stranger, proud. The Armenians' fullness of life, their rough tenderness, their noble inclination for hard work, their inexplicable aversion to any kind of metaphysics, and their splendid intimacy with the world of real things-all this said to me: you're awake, don't be afraid of your own time, don't be sly.

Wasn't this because I found myself among people, renowned for their teeming activity, who nevertheless told time not by the railroad station or the office clock, but by the sundial, such as the one I saw among the ruins of $Z$ vartnots in the form of the zodiac or of a rose inscribed in stone? ${ }^{38}$

Mandelstam's farewell journey - the longer ones he was to make were not of his own choosing - reinvigorated him and renewed his gift. "Parting," he wrote, "is the younger sister of death," and his departure from Armenia, "the younger sister of Judea," was a preparation for death. ${ }^{39}$ The apocalyptic theme is unmistakable. Yet Mandelstam's apocalypse is also an apokothastasis: he looks forward not only to the end, but also to resurrection and renewal. Amidst the crumbling of walls and exhaustion of phonetic ores, he counts on "the complicity of those united in a conspiracy against emptiness and nonbeing." 40

A world come to an end; the world goes on. 